\title{
Effect of the Phosphodiesterase 5 Inhibitor Sildenafil on Ischemia-Reperfusion-Induced Muscle Mitochondrial Dysfunction and Oxidative Stress
}

\author{
Liliane Tetsi ${ }^{1}$, Anne-Laure Charles ${ }^{1}$, Isabelle Georg ${ }^{1}$, Fabienne Goupilleau ${ }^{1}$, Anne Lejay ${ }^{1,2,3}$, \\ Samy Talha ${ }^{1,2}$, Myriam Maumy-Bertrand ${ }^{4}$, Claire Lugnier ${ }^{1}\left[\right.$ and Bernard Geny ${ }^{1,2, *}$ \\ 1 Unistra, Fédération de Médecine Translationnelle, Equipe d'Accueil 3072, « Mitochondrie, Stress oxydant et \\ Protection Musculaire », Institut de Physiologie, 67000 CEDEX, France; gemmelere@yahoo.fr (L.T.); \\ anne.laure.charles@unistra.fr (A.-L.C.); isabelle.georg@unistra.fr (I.G.); goupilleau@unistra.fr (F.G.); \\ anne.lejay@chru-strasbourg.fr (A.L.); samy.talha@chru-strasbourg.fr (S.T.); claire.lugnier@unistra.fr (C.L.) \\ 2 Hôpitaux Universitaires de Strasbourg, Service de Physiologie et d'Explorations Fonctionnelles, \\ 67000 Strasbourg, France \\ 3 Hôpitaux Universitaires de Strasbourg, Service de Chirurgie vasculaire et de transplantation rénale, \\ 67000 Strasbourg, France \\ 4 IRMA, équipe MoCo et LabEx IRMIA, 7 rue René Descartes, 67084 Strasbourg CEDEX, France; \\ mmaumy@math.unistra.fr \\ * Correspondence: bernard.geny@chru-strasbourg.fr; Tel.: +33-3-69-55-06-60 or +03-69-55-08-79; \\ Fax: +33-3-69-55-18-26
}

Received: 28 March 2019; Accepted: 5 April 2019; Published: 7 April 2019

\begin{abstract}
Lower-limb ischemia-reperfusion (IR) is frequent and associated with significant morbidity and mortality. Phosphodiesterase 5 inhibitors demonstrated antioxidant and beneficial effects in several organs submitted to IR, but their effects on muscle mitochondrial functions after lower-limb IR are unknown. Unilateral hindlimb IR ( $2 \mathrm{~h}$ tourniquet followed by $2 \mathrm{~h}$ reperfusion) without or with sildenafil (1mg/kg ip 30 minutes before ischemia) was performed in 18 mice. Maximal oxidative capacity $\left(\mathrm{V}_{\mathrm{Max}}\right)$, relative contribution of the mitochondrial respiratory chain complexes, calcium retention capacity (CRC) - a marker of apoptosis—and reactive oxygen species (ROS) production were determined using high-resolution respirometry, spectrofluorometry, and electron paramagnetic resonance in gastrocnemius muscles from both hindlimbs. IR significantly reduced mitochondrial $\mathrm{V}_{\text {Max }}$ (from $11.79 \pm 1.74$ to $4.65 \pm 1.11 \mathrm{pmol} / \mathrm{s}^{*} \mathrm{mg}$ wet weight (ww), $p<0.05,-50.2 \pm 16.3 \%$ ) and CRC (from $2.33 \pm 0.41$ to $0.84 \pm 0.18 \mu \mathrm{mol} / \mathrm{mg}$ dry weight (dw),$p<0.05 ;-61.1 \pm 6.8 \%$ ). ROS tended to increase in the ischemic limb $(+64.3 \pm 31.9 \%, p=0.08)$. Although tending to reduce IR-related ROS production $(-42.4 \%)$, sildenafil failed to reduce muscle mitochondrial dysfunctions $(-63.3 \pm 9.2 \%$, $p<0.001$ and $-55.2 \pm 7.6 \% p<0.01$ for $\mathrm{V}_{\mathrm{Max}}$, and CRC, respectively). In conclusion, lower limb IR impaired skeletal muscle mitochondrial function, but, despite tending to reduce ROS production, pharmacological preconditioning with sildenafil did not show protective effects.
\end{abstract}

Keywords: cyclic nucleotide phosphodiesterase; sildenafil; muscle; ischemia; reperfusion; peripheral arterial disease; mitochondria; reactive oxygen species; oxidative stress; calcic retention capacity

\section{Introduction}

Peripheral arterial disease (PAD) is frequent and associated with significant morbidity and mortality [1,2]. PAD overall prevalence ranges from $3 \%$ to $10 \%$, increasing to $15-20 \%$ in persons older than 70 years of age [3]. The annual incidence of critical limb ischemia in patients admitted to hospital between 2003 and 2011 was 150 per 100,000 people in the United States [4]. The causes 
of PAD are multiple, related to general (wound, contusion, compression) or local arterial injuries (atherosclerosis, embolic events, thrombosis, dissections of the arterial wall) and result finally in vessel obstruction leading to limb ischemia [5]. Lower limb ischemia requires surgical revascularization, possibly associated with thrombolysis, but revascularization might be impossible in some cases, highlighting the need for new therapeutic approaches $[2,6]$.

Recent improvement in the knowledge of PAD pathophysiology might be useful to open new therapeutic approaches. Thus, skeletal muscle mitochondrial dysfunctions, together with increased reactive oxygen species (ROS) production are key factors. Mitochondria play a central role in cell homeostasis, since they are the primary sites of energy production through ATP synthesis. Besides cellular energy metabolism adaptation, such organelles also modulate the production of ROS and consequently cell apoptosis, which is increased when mitochondrial calcic retention capacity (CRC) is impaired [7-10]. Interestingly, if ischemia per se is clearly deleterious and urges to perform revascularization procedures, the reperfusion period is also responsible for deleterious effects relying importantly on the amount of ROS released. Thus, after aortic cross-clamping, increased oxidative stress precedes mitochondrial dysfunction [11].

Ischemic preconditioning generally demonstrated to be protective in lower limb ischemia-reperfusion [12,13]. Ischemic post-conditioning can also reduce oxidative stress and preserve antioxidant defense in an experimental model of aortic clamping [14] but it has also been shown to be deleterious [15]. These data pave the way to develop pharmacological approaches. Cyclosporine A demonstrated promising results by protecting muscle in young rats but was disappointing when investigating old animals submitted to lower limb ischemia-reperfusion (IR) with tourniquet use [16,17]. Interestingly, confirming data previously obtained in the setting of myocardial infarction [18], we observed that the cardiac hormone brain natriuretic peptide (BNP) reduced skeletal muscle mitochondrial dysfunction and oxidative stress after acute lower limb IR [19]. Since BNP main actions are mediated by an increase in the second intracellular messenger cyclic guanylyl monophosphate (cGMP), another approach aiming to reduce cGMP degradation might be interesting.

In this view, phosphodiesterase inhibition deserves to be investigated. Cyclic nucleotide phosphodiesterase families (PDEs) control cyclic nucleotide levels and play a major role in the control of normal and pathological cellular signaling [20-22]. Particularly, the PDE5 family hydrolyzes specifically cGMP, and its inhibition increases cGMP levels. Sildenafil, a well-known PDE5 inhibitor, is widely used in humans mainly for treating pulmonary hypertension and erectile dysfunctions [23]. It also induced protective effects during ischemia-reperfusion on several organs [24-29], supporting its potential usefulness in IR settings. PDE5 has been also shown to be expressed in skeletal muscle [21,30], and, accordingly, sildenafil reduced muscle oxidative stress and/or increased muscle angiogenesis and reduced inflammation 7 or 30 days after either femoral artery removal or unilateral hindlimb IR [31-33].

The aim of this study was, therefore, to investigate whether pharmacological pre-conditioning with the PDE5 inhibitor might, through its anti-oxidant effect, protect skeletal muscle mitochondrial oxidative capacity and calcium retention capacity, using the model of tourniquet-induced lower limb IR.

\section{Material and Methods}

\subsection{Animals}

Eighteen male Swiss mice (12-16 week old), provided by JANVIER Labs (Saint Berthevin, France), were housed in a thermo-neutral environment at $22 \pm 2{ }^{\circ} \mathrm{C}$ on a $12 \mathrm{~h}$ day/night cycle and were provided food and water ad libitum. The protocol was approved by the Regional Committee of Ethics in Animal Experimentation of Strasbourg (C.R.E.M.E.A.S) and the Ministry of Higher Education and Research (CREMEAS n²018022716192465v3), and the animal care complied with the Guide for the Care and Use of Laboratory Animals, Institute of Laboratory Animal Resources, Commission on Life Sciences, National Research Council. Washington: National Academy Press, 1996. 


\subsection{Experimental Design}

All mice were subjected to $2 \mathrm{~h}$ ischemia through a tourniquet placed on the right hindlimb, followed by $2 \mathrm{~h}$ reperfusion (Figure 1). The left non-ischemic hindlimb served as a control, since previous data demonstrated that unilateral limb ischemia did not significantly affect the contralateral limb [34]. Thirty minutes before ischemia, sham mice $(\mathrm{n}=8)$ received intraperitoneal $\mathrm{NaCl} 9 \%(5 \mu \mathrm{L} / \mathrm{g})$, and sildenafil mice ( $\mathrm{n}=10$ mice) received intraperitoneally sildenafil $/ \mathrm{NaCl} 9 \%(1 \mathrm{mg} / \mathrm{kg})$. Mice were then placed in a hermetic anaesthetic induction cage, ventilated with a gas mixture of $4 \%$ isoflurane (AERRANE ${ }^{\circledR}$, BAXTER S.A.S.) and oxygen and placed on heating blankets (MINERVE ${ }^{\circledR}$, Esternay, France) at $37^{\circ} \mathrm{C}$. Spontaneous ventilation was allowed through an oxygen-delivering mask, with different concentrations of isoflurane depending on the surgical stage ( $2 \%$ during painful stimuli and $1 \%$ during latent periods). At the end of the experiment, left and right gastrocnemius muscles were dissected and immediately immersed in Krebs solution at $4{ }^{\circ} \mathrm{C}$ for the extemporaneous analyses of mitochondrial functions.
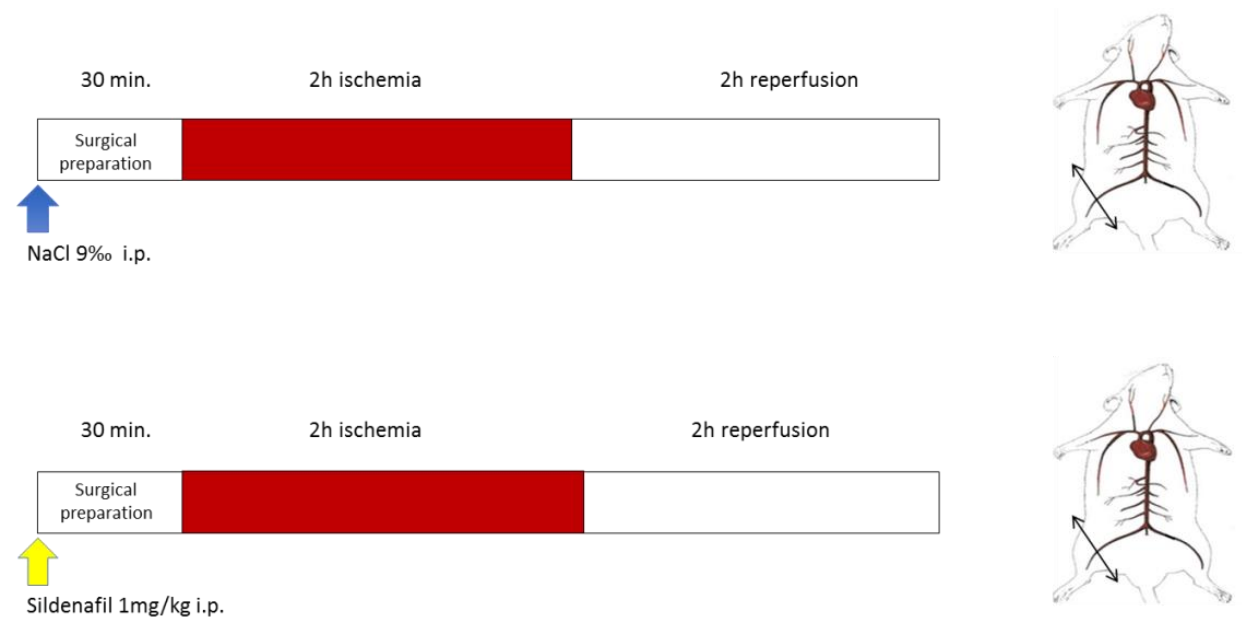

Figure 1. Experimental design. Top ( $\mathrm{NaCl}$ ): Ischemia-reperfusion (IR) animals underwent $2 \mathrm{~h}$ of unilateral hind limb tourniquet ischemia (red bar), followed by $2 \mathrm{~h}$ of reperfusion (open bar). The right, non-ischemic hind limb served as a control, and Nacl was administered ip $30 \mathrm{~min}$ before ischemia. Bottom (Sildenafil + IR): the same protocol was performed, but $1 \mathrm{mg} / \mathrm{kg}$ sildenafil $/ \mathrm{NaCl}$ ip was administered.

\subsection{Mitochondrial Respiratory Chain Complex Activities}

Muscle oxygen consumption was determined using a high-resolution oxygraph (Oxygraph 2K, Oroboros instruments, Innsbruck, Austria), in $2 \mathrm{ml}$ of Miro5 $+\mathrm{Cr}$ thermostated at $37^{\circ} \mathrm{C}$, containing EGTA $(0.5 \mathrm{mM}), \mathrm{MgCl}_{2}(3 \mathrm{mM}), \mathrm{K}$ lactobionate $(60 \mathrm{mM})$, taurine $(20 \mathrm{mM}), \mathrm{KH}_{2} \mathrm{PO}_{4}(10 \mathrm{mM}), \mathrm{HEPES}$ $(20 \mathrm{mM})$, sucrose $(110 \mathrm{mM})$, creatine $(20 \mathrm{mM})$, BSA $(1 \mathrm{~g} / \mathrm{L})$.

Permeabilized fibers were placed in chambers to record the basal oxygen consumption $\left(\mathrm{V}_{0}\right)$ with glutamate $(10 \mathrm{mM})$ and malate $(2.5 \mathrm{mM})$. Then, maximal respiration rate $\left(\mathrm{V}_{\mathrm{Max}}\right)$ was measured under continuous stirring in the presence of saturating amount of ADP $(2 \mathrm{mM})$ as a phosphate acceptor. Succinate injection $\left(25 \mathrm{mM}, \mathrm{V}_{\text {succ }}\right)$ allowed the activation of all complexes (I, II, III, IV, V). Finally, ascorbate $(0.5 \mathrm{mM})$ and $\mathrm{N}, \mathrm{N}, \mathrm{N}^{\prime}$ ', N'-tetramethyl-p-phenylenediamine dihydrochloride (TMPD, $0.5 \mathrm{mM}$ ) were injected, $\mathrm{V}_{\text {asc/TMPD }}$ representing the complex IV contribution. Results were expressed as $\mathrm{pmol} / \mathrm{sec} / \mathrm{mg}$ wet weight.

\subsection{Calcium Retention Capacity (CRC) Measurements in Gastrocnemius Ghost Fibers}

The time to the opening of the mitochondrial permeability transition pore (mPTP) following $\mathrm{Ca}^{2+}$ challenge ( $5 \mu \mathrm{L}$ of $\mathrm{Ca}^{2+}, 1 \mathrm{mM}$, pulses performed every $5 \mathrm{~min}$ ) was determined in permeabilized "ghost" muscle fibers [23]. The amount of $\mathrm{Ca}^{2+}$ needed to trigger a massive $\mathrm{Ca}^{2+}$ release by the mitochondria due to mPTP opening was calculated from a standard curve relating $\left[\mathrm{Ca}^{2+}\right]$ to the fluorescence of calcium green and expressed as $\mu \mathrm{mol} / \mathrm{mg}$ dry weight. 


\subsection{Production of Reactive Oxygen Species Using Electron Paramagnetic Resonance}

Immediately after harvesting, gastrocnemius muscles were placed in Krebs solution containing $\mathrm{NaCl}$ $99 \mathrm{mM}, \mathrm{KCl} 4.69 \mathrm{mM}, \mathrm{CaCl}_{2} 2.5 \mathrm{mM}, \mathrm{MgSO}_{4} 1.2 \mathrm{mM}, \mathrm{NaHCO}_{3} 25 \mathrm{mM}, \mathrm{KH}_{2} \mathrm{PO}_{4} 1.03 \mathrm{mM}, \mathrm{D}(+)$ glucose $5.6 \mathrm{mM}$, Na-Hepes $20 \mathrm{mM}$, deferoxamine $25 \mu \mathrm{M}$, and DETC $5 \mu \mathrm{M}$. Tissues were cut into 1 to $2 \mathrm{~mm}^{3}$ slices and incubated for $30 \mathrm{~min}$ with 1-hydroxy-3-methoxycarbonyl-2, 2, 5, 5-tetramethylpyrrolidine $\mathrm{HCl}(\mathrm{CMH})$ in a thermo-regulated incubator $\left(37^{\circ} \mathrm{C}\right)$ under controlled pressure $(20 \mathrm{mmHg})$ and gas mix $\left(\mathrm{N}_{2}: 97.8 \%, \mathrm{O}_{2}\right.$ : $2.8 \%$ ) (Noxygen ${ }^{\circledR}$, Germany). EPR spectroscopy (Bruker Win-EPR ${ }^{\circledR}$, Bruker Analytik, GmbH) was used to determine ROS production, expressed in $\mu \mathrm{mol} / \mathrm{min} / \mathrm{mg}$ dry weight.

\section{Statistical Analysis}

All results were expressed as means \pm SEM. Data were analysed using Prism software (GraphPad Prism 5, Graph Pad Software, Inc., San Diego, CA, USA), and differences between groups were assessed using two-way ANOVA test, followed by the Bonferroni post-test.

To determine the precise $p$ value when considering ROS, paired t-test was performed. A $p$ value $<0.05$ was considered significant.

\section{Results}

4.1. Lower-Limb Ischemia-Reperfusion Impaired Skeletal Muscle Mitochondrial Respiration and Calcium Retention Capacity and Tended to Increase ROS Production

\subsubsection{Mitochondrial Respiration}

Two $\mathrm{h}$ ischemia followed by $2 \mathrm{~h}$ reperfusion significantly decreased $\mathrm{V}_{0}$ (basal oxygen consumption rate) of ischemic limbs, as compared to contralateral non-ischemic limbs (7.58 $\pm 1.16 \mathrm{vs}$ $2.63 \pm 0.74 \mathrm{pmolO}_{2} / \mathrm{s} / \mathrm{mg}$ wet weight $(\mathrm{ww}),-62.8 \pm 9.5 \%, p<0.01$, in non-ischemic and ischemic limbs, respectively, Figure 2).
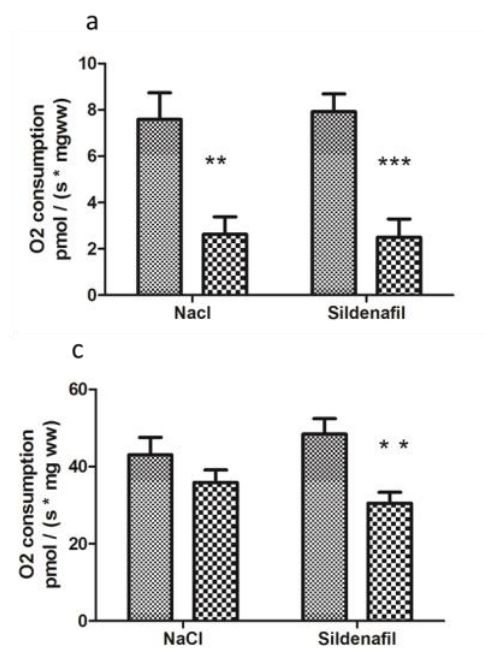
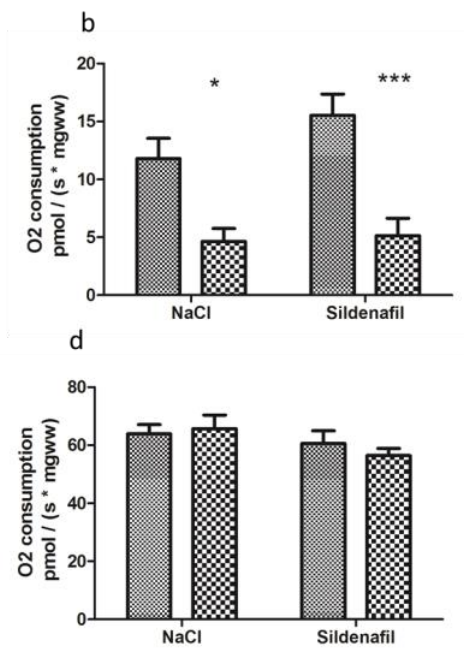

Figure 2. Mitochondrial respiration in ischemic and non-ischemic gastrocnemius in mice treated $(n=10)$ or not $(n=8)$ with sildenafil; $(\mathbf{a}): \mathrm{V}_{0}$ corresponds to the basal $\mathrm{O}_{2}$ consumption, with glutamate and malate as substrates. (b): $\mathrm{V}_{\max }$ corresponds to the ADP-stimulated respiration, with glutamate and malate as substrates. (c): $\mathrm{V}_{\text {succ }}$ represents the activation of all complexes (I, II, III, IV, V). (d): $\mathrm{V}_{\text {asc/TMPD }}$ represents the complex IV contribution to the global mitochondrial respiratory rate. For both $\mathrm{NaCl}$ and Sildenafil groups: left column, non-ischemic contralateral limb. Right column: Ischemic limb. Results are expressed as means \pm SEM. ${ }^{*}: p<0.05 ;{ }^{* *}: p<0.01$ and ${ }^{* * *}: p<0.001$, as compared to the contralateral limb of the same group. 
Maximal mitochondrial respiration rate, $\mathrm{V}_{\max }$, which corresponds to complexes I, III, IV, and V of the mitochondrial respiratory chain, decreased from $11.79 \pm 1.74$ to $4.65 \pm 1.11 \mathrm{pmolO}_{2} / \mathrm{s} / \mathrm{mg}$ ww $(-50.2 \pm 16.3 \% p<0.05$, Figure 2$)$.

$\mathrm{V}_{\text {succ, }}$ (activity of complexes I, II, III, IV, and V) decreased from $43.03 \pm 4.55$ to $35.85 \pm 3.24 \mathrm{pmolO}_{2} / \mathrm{s} / \mathrm{mg}$ ww $(-11.6 \pm 9.9 \%$, Figure 2$)$.

Finally, $\mathrm{V}_{\text {asc }} / \mathrm{TMPD}$, reflecting more specifically the activity of complex IV, was not significantly modified $\left(63.89 \pm 3.19\right.$ vs $65.68 \pm 4.70 \mathrm{pmolO}_{2} / \mathrm{s} / \mathrm{mg} \mathrm{ww}$, Figure 2 .

\subsubsection{Calcium Retention Capacity (CRC)}

IR significantly decreased skeletal muscles' CRC in ischemic limbs ( $2.33 \pm 0.41$ vs $0.84 \pm 0.18$ $\mu \mathrm{mol} / \mathrm{mg}$ dry weight $(\mathrm{dw}) ;-61.1 \pm 6.8 \% p<0.01$, Figure 3$)$ in ischemic vs non-ischemic limbs.

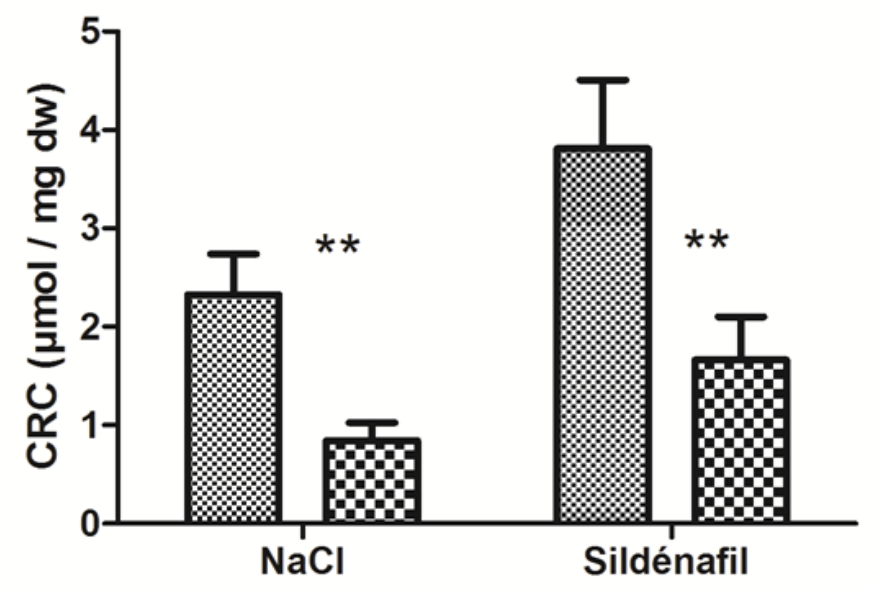

Figure 3. Calcium retention capacity $(\mathrm{CRC})$ in ischemic and non-ischemic gastrocnemius in mice treated $(n=7)$ or not $(n=9)$ with sildenafil. For both $\mathrm{NaCl}$ and Sildenafil groups: left column, non-ischemic contralateral limb. Right column: Ischemic limb. Results are expressed as means \pm SEM. ${ }^{* *}: p<0.01$.

\subsubsection{Oxidative Stress}

Production of ROS was $0.08 \pm 0.01$ in the non-ischemic limbs and $0.13 \pm 0.02 \mu \mathrm{mol} / \mathrm{min} / \mathrm{mg} \mathrm{dw}$ in the ischemic limbs $(+64.3 \pm 31.9 \% ; p=0.08)$, as seen in Figure 4 .

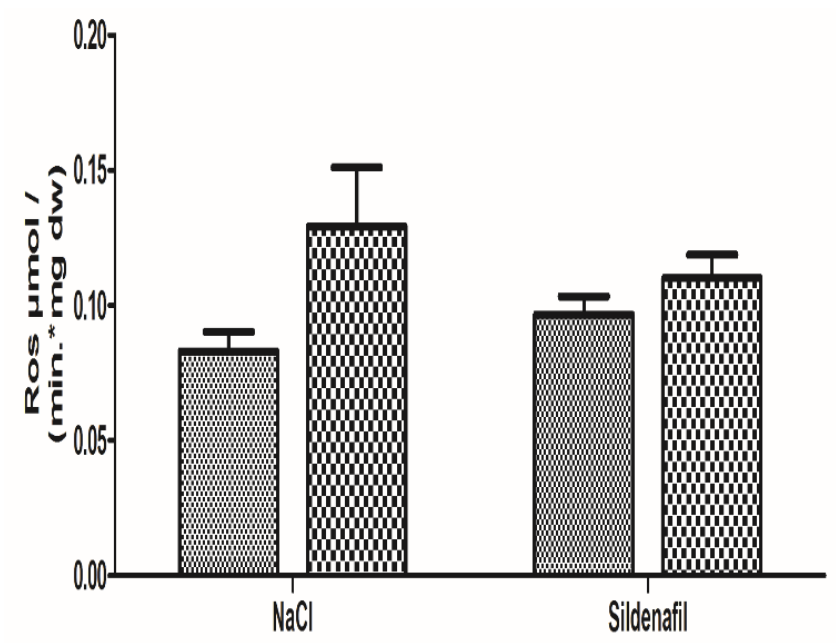

Figure 4. Reactive Oxygen species (ROS) production in ischemic and non-ischemic gastrocnemius in mice treated $(n=8)$ or not $(n=8)$ with sildenafil. ROS level was obtained using electron paramagnetic resonance. For both $\mathrm{NaCl}$ and Sildenafil groups: left column, non-ischemic contralateral limb. Right column: Ischemic limb. Results are expressed as means \pm SEM. $p=0.08$ in the NaCl group. 
4.2. Sildenafil Did Not Protect Skeletal Muscle Mitochondrial Respiration and Calcium Retention Capacity, Albeit Tending to Reduce ROS Production

\subsubsection{Mitochondrial Respiration}

In sildenafil-treated mice, $\mathrm{V}_{0}$ was reduced $\left(7.70 \pm 0.64\right.$ vs $2.83 \pm 0.80 \mathrm{pmolO}_{2} / \mathrm{s} / \mathrm{mg}$ ww; $-62.9 \pm 10.8 \% p<0.001$, Figure 2) in ischemic limbs.

$\mathrm{V}_{\max }$ decreased from $15.29 \pm 1.75$ to $5.74 \pm 1.47 \mathrm{pmolO}_{2} / \mathrm{s} / \mathrm{mg} \mathrm{ww},(-63.3 \pm 9.2 \% p<0.001$, Figure 2).

$\mathrm{V}_{\text {succ }}$ decreased from $48.37 \pm 4.02$ to $31.63 \pm 2.65 \mathrm{pmolO}_{2} / \mathrm{s} / \mathrm{mg}$ ww in ischemic limbs $(-30.4 \pm 7.9 \% p<0.01$, Figure 2$)$.

$\mathrm{V}_{\text {asc } / \mathrm{TMPD}}$ was $61.49 \pm 3.94$ in contralateral limbs and $56.72 \pm 2.43 \mathrm{pmolO}_{2} / \mathrm{s} / \mathrm{mg}$ ww in ischemic limbs, $p$ was not significant (Figure 2).

\subsubsection{Calcium Retention Capacity (CRC)}

In sildenafil-treated mice, CRC decreased from $3.81 \pm 0.70$ (non-ischemic limbs) to $1.66 \pm 0.44$ $\mu \mathrm{mol} / \mathrm{mg} \mathrm{dw}$ (ischemic limbs), $(-55.2 \pm 7.6 \%$, with $p<0.01$, Figure 3 ).

\subsubsection{Oxidative Stress}

Production of ROS in sildenafil-treated mice was $0.10 \pm 0.01$ in the non-ischemic limbs and $0.11 \pm 0.01 \mu \mathrm{mol} / \mathrm{min} / \mathrm{mgdw}$ in the ischemic limbs $(+21.9 \pm 16.6 \%, p=0.34)$, as shown in Figure 4 .

The sildenafil-related reduction in ROS production ( $-42.4 \%$, as compared to the $\mathrm{NaCl}$ group) failed to reach statistical significance.

\section{Discussion}

The main findings of this study are that lower limb IR impaired mitochondrial oxidative capacity and decreased calcium retention capacity in skeletal muscle. Further, albeit reducing ROS production, acute preconditioning with the phosphodiesterase 5 inhibitor sildenafil did not reduce IR-induced muscle injuries.

\subsection{Effects of Ischemia-Reperfusion}

Using different substrates, we observed that the functional activities of the main mitochondrial respiratory chain complexes were impaired by IR. The gastrocnemius muscle was chosen in view of its susceptibility to IR injuries [35,36], allowing it to be a key target when investigating new therapeutic approaches. Thus, main mitochondrial complexes showed a significant decrease in their oxidative capacity, and ROS production tended to be increased. These data are in accordance with results previously obtained with lower limb IR models, secondary to aortic ligation or unilateral leg IR, which demonstrated reduced skeletal muscle oxidative capacities together with increased ROS production [13-17,19,37,38]. Accordingly, oxidative damage in the gastrocnemius has been observed in patients with peripheral artery disease [39]. Interestingly, IR also induced a reduction in mitochondrial calcium retention capacity. This corresponded to a rapid opening of the mitochondrial permeability transition pore, leading thereby to cell apoptosis.

\subsection{Effects of Sildenafil}

Several studies previously reported a protective effect of sildenafil in IR settings. Thus, sildenafil protection was reported during acute cardiac IR in mouse [40], in the human heart [25], as well in the kidney [26], lung [27], liver [28], and brain [29]. Further, another phosphodiesterase 5 inhibitor, vardenafil, improved vascular graft function [41]. Taken together and considering the fact that PDE5 expression has been observed in skeletal muscles [21,30,42], these data suggest that PDE5 might also be implicated in skeletal muscle IR. 
Accordingly, chronic administration of sildenafil improved ischemia-induced neovascularization in hypercholesterolemic apolipoprotein E-deficient mice, reduced TNF alpha staining in the femoral artery, and reduced inflammation and oxidative stress in skeletal muscle [31-33].

Nevertheless, our study shows that, although tending to decrease ROS production in line with literature data obtained both in skeletal and in cardiac muscles [31,43], sildenafil did not overcome the deleterious effects of acute IR on skeletal muscle. This was unexpected, since we previously observed that BNP, also known to increase the second messenger cGMP, protected skeletal muscle in a similar setting [19].

One explanation might be that chronic treatment might be mandatory. Indeed, beneficial effects of sildenafil were observed after daily, weekly, or even longer administration [31-33]. However, acute sildenafil administration also demonstrated some degrees of protection [44-46]. In these cases, the PDE5 inhibitor was administered either prior to ischemia or $30 \mathrm{~min}$ before reperfusion and after release of the clamps [44-46]. Similarly, we administrated sildenafil 30 minutes before ischemia to allow a large diffusion in muscles. Indeed, maximal concentration occurred $1 \mathrm{~h}$ after a single intravenous administration, and the half-life was around $0.4-1.3 \mathrm{~h}$ in rodents [47]. These studies, nevertheless, investigated mainly environmental changes in muscles, focusing on the inflammatory status. Thus, muscular changes consisted principally in reduced inflammatory cells and TNF alpha staining [44,45]. Necrosis was not reduced when using sildenafil alone [45]. Particularly, no previous data have been reported concerning the specific effect of sildenafil on IR-induced skeletal muscle mitochondrial dysfunctions, but, interestingly, sildenafil reduced caspase 3, which is considered a marker of apoptosis, only at a late stage $(24 \mathrm{~h})$ of reperfusion. No significant change was observed at $4 \mathrm{~h}$ of reperfusion [46].

In line with our results, Nio et al. [48] reported only a slight mRNA expression of PDE5 in gastrocnemius and, contrary to data obtained in the lung and the heart, oral sildenafil at a single dose of $30 \mathrm{mg} / \mathrm{kg}$ did not increase cGMP in such muscle [48]. Thus, a low physiological level of intracellular cGMP and/or a low amount of PDE type 5 in the gastrocnemius muscle might suggest a longer or greater exposure to sildenafil in order to protect skeletal muscle.

Thus, higher sildenafil doses might deserve further discussion. Higher dosages (40 and $10 \mathrm{mg} / \mathrm{Kg}$ ) of oral sildenafil have been previously used [31,33]. However, $1 \mathrm{mg} / \mathrm{Kg}$ sildenafil also showed beneficial effects using different administration modalities (per os, ip, iv) [32,44-46]. In our setting, administering $1 \mathrm{mg} / \mathrm{Kg}$ sildenafil for two times and combining pre- and post-conditioning might deserve further investigations.

\section{Conclusions}

Lower limb IR significantly impairs skeletal muscle mitochondrial functions. However, although beneficial in other IR settings and despite its tendency to decrease ROS production, acute pharmacologic preconditioning with the phosphodiesterase 5 inhibitor sildenafil did not reduce IR-induced impairments in mitochondrial oxidative and calcium retention capacities in skeletal muscle. Further studies will be useful to further determine the functional roles of PDE and cGMP and to investigate mitochondria-targeted antioxidants in normal and ischemic skeletal muscles [49].

Author Contributions: Formal analysis, L.T., A.-L.C., A.L., S.T., M.M.-B., C.L. and B.G.; Investigation, L.T., A.-L.C., I.G., F.G. and A.L.; Methodology, L.T., A.-L.C., I.G., F.G., A.L., S.T., M.M.-B., C.L. and B.G.; Supervision, C.L. and B.G.; Validation, L.T., A.-L.C., I.G., F.G., A.L., S.T., M.M.-B., C.L. and B.G.; Writing - original draft, L.T., A.-L.C., C.L. and B.G.; Writing - review \& editing, B.G.

Funding: This research received no external funding.

Acknowledgments: We are grateful to Anne-Marie Kasprowicz for her skillful secretarial assistance.

Conflicts of Interest: There are no conflicts of interest. 


\section{References}

1. Criqui, M.H.; Aboyans, V. Epidemiology of peripheral artery disease. Circ. Res. 2015, 116, 1509-1526. [CrossRef] [PubMed]

2. Aboyans, V.; Ricco, J.B.; Bartelink, M.E.L.; Björck, M.; Brodmann, M.; Cohnert, T.; Collet, J.P.; Czerny, M.; De Carlo, M.; Debus, S.; et al. 2017 ESC guidelines on the diagnosis and treatment of peripheral arterial diseases, in collaboration with the european society for vascular surgery (ESVS). Eur. J. Vasc. Endovasc. Surg. 2018, 55, 305-368. [CrossRef] [PubMed]

3. Dua, A.; Lee, C.J. Epidemiology of peripheral arterial disease and critical limb ischemia. Tech. Vasc. Interv. Radiol. 2016, 19, 91-95. [CrossRef] [PubMed]

4. Agarwal, S.; Sud, K.; Shishehbor, M.H. Nationwide trends of hospital admission and outcomes among critical limb ischemia patients: From 2003-2011. J. Am. Coll. Cardiol. 2016, 67, 1901-1913. [CrossRef] [PubMed]

5. Uccioli, L.; Meloni, M.; Izzo, V.; Giurato, L.; Merolla, S.; Gandini, R. Critical limb ischemia: Current challenges and future prospects. Vasc. Health Risk Manag. 2018, 14, 63-74. [CrossRef]

6. Kropman, R.H.J.; Schrijver, A.M.; Kelder, J.C.; Moll, F.L.; de Vries, J.P.P.M. Clinical outcome of acute leg ischaemia due to thrombosed popliteal artery aneurysm: Systematic review of 895 cases. Eur. J. Vasc. Endovasc. Surg. 2010, 39, 452-457. [CrossRef] [PubMed]

7. Ismaeel, A.; Brumberg, R.S.; Kirk, J.S.; Papoutsi, E.; Farmer, P.J.; Bohannon, W.T.; Smith, R.S.; Eidson, J.L.; Sawicki, I.; Koutakis, P. Oxidative stress and arterial dysfunction in peripheral artery disease. Antioxidants 2018, 7, 145. [CrossRef]

8. Duteil, D.; Chambon, C.; Ali, F.; Malivindi, R.; Zoll, J.; Kato, S.; Geny, B.; Chambon, P.; Metzger, D. The transcriptional coregulators TIF2 and SRC-1 regulate energy homeostasis by modulating mitochondrial respiration in skeletal muscles. Cell Metab. 2010, 12, 496-508. [CrossRef] [PubMed]

9. Lejay, A.; Meyer, A.; Schlagowski, A.I.; Charles, A.L.; Singh, F.; Bouitbir, J.; Pottecher, J.; Chakfé, N.; Zoll, J.; Geny, B. Mitochondria: Mitochondrial participation in ischemia-reperfusion injury in skeletal muscle. Int. J. Biochem. Cell Biol. 2014, 50, 101-105. [CrossRef] [PubMed]

10. Paradis, S.; Charles, A.L.; Meyer, A.; Lejay, A.; Scholey, J.W.; Chakfé, N.; Zoll, J.; Geny, B. Chronology of mitochondrial and cellular events during skeletal muscle ischemia-reperfusion. Am. J. Physiol. Cell Physiol. 2016, 310, 968-982. [CrossRef]

11. Guillot, M.; Charles, A.L.; Chamaraux-Tran, T.N.; Bouitbir, J.; Meyer, A.; Zoll, J.; Schneider, F.; Geny, B. Oxidative stress precedes skeletal muscle mitochondrial dysfunction during experimental aortic cross-clamping but is not associated with early lung, heart, brain, liver, or kidney mitochondrial impairment. J Vasc. Surg. 2014, 60, 1043-1051. [CrossRef] [PubMed]

12. Ali, Z.A.; Callaghan, C.J.; Lim, E.; Ali, A.A.; Nouraei, S.A.; Akthar, A.M.; Boyle, J.R.; Varty, K.; Kharbanda, R.K.; Dutka, D.P.; et al. Remote ischemic preconditioning reduces myocardial and renal injury after elective abdominal aortic aneurysm repair: A randomized controlled trial. Circulation 2007, 116, 98-105. [CrossRef]

13. Mansour, Z.; Bouitbir, J.; Charles, A.L.; Talha, S.; Kindo, M.; Pottecher, J.; Zoll, J.; Geny, B. Remote and local ischemic preconditioning equivalently protects rat skeletal muscle mitochondrial function during experimental aortic cross-clamping. J. Vasc. Surg. 2012, 55, 497-505. [CrossRef]

14. Charles, A.L.; Guilbert, A.S.; Bouitbir, J.; Goette-Di Marco, P.; Enache, I.; Zoll, J.; Piquard, F.; Geny, B. Effect of postconditioning on mitochondrial dysfunction in experimental aortic cross-clamping. Br. J. Surg. 2011, 98, 511-516. [CrossRef]

15. Mansour, Z.; Charles, A.L.; Bouitbir, J.; Pottecher, J.; Kindo, M.; Mazzucotelli, J.P.; Zoll, J.; Geny, B. Remote and local ischemic postconditioning further impaired skeletal muscle mitochondrial function after ischemia-reperfusion. J. Vasc. Surg. 2012, 56, 774-782. [CrossRef]

16. Pottecher, J.; Guillot, M.; Belaidi, E.; Charles, A.L.; Lejay, A.; Gharib, A.; Diemunsch, P.; Geny, B. Cyclosporine A normalizes mitochondrial coupling, reactive oxygen species production, and inflammation and partially restores skeletal muscle maximal oxidative capacity in experimental aortic cross-clamping. J. Vasc. Surg. 2013, 57, 1100-1108. [CrossRef] [PubMed]

17. Pottecher, J.; Kindo, M.; Chamaraux-Tran, T.N.; Charles, A.L.; Lejay, A.; Kemmel, V.; Vogel, T.; Chakfe, N.; Zoll, J.; Diemunsch, P.; et al. Skeletal muscle ischemia-reperfusion injury and cyclosporine A in the aging rat. Fundam. Clin. Pharmacol. 2016, 30, 216-225. [CrossRef] 
18. D'Souza, S.P.; Yellon, D.M.; Martin, C.; Schulz, R.; Heusch, G.; Onody, A.; Ferdinandy, P.; Baxter, G.F. B-type natriuretic peptide limits infarct size in rat isolated hearts via KATP channel opening. Am. J. Physiol. Heart Circ. Physiol. 2003, 284, H1592-H1600. [CrossRef]

19. Talha, S.; Bouitbir, J.; Charles, A.; Zoll, J.; Goette-Di Marco, P.; Meziani, F.; Piquard, F.; Geny, B. Pretreatment with brain natriuretic peptide reduces skeletal muscle mitochondrial dysfunction and oxidative stress after ischemia-reperfusion. J. Appl. Physiol. 2013, 114, 172-179. [CrossRef]

20. Keravis, T.; Lugnier, C. Cyclic nucleotide phosphodiesterase (PDE) isozymes as targets of the intracellular signalling network: Benefits of PDE inhibitors in various diseases and perspectives for future therapeutic developments. Br. J. Pharmacol. 2012, 165, 1288-1305. [CrossRef]

21. Maurice, D.H.; Ke, H.; Ahmad, F.; Wang, Y.; Chung, J.; Manganiello, V.C. Advances in targeting cyclic nucleotide phosphodiesterases. Nat. Rev. Drug Discov. 2014, 13, 290-314. [CrossRef] [PubMed]

22. Tetsi, L.; Charles, A.L.; Paradis, S.; Lejay, A.; Talha, S.; Geny, B.; Lugnier, C. Effects of cyclic nucleotide phosphodiesterases (PDEs) on mitochondrial skeletal muscle functions. Cell. Mol. Life Sci. 2017, 74, 1883-1893. [CrossRef]

23. Andersson, K.E. PDE5 inhibitors-Pharmacology and clinical applications 20 years after sildenafil discovery. Br. J. Pharmacol. 2018, 75, 2554-2565. [CrossRef]

24. Wang, G.; Zhang, Q.; Yuan, W.; Wu, J.; Li, C. Sildenafil protects against myocardial ischemia-reperfusion injury following cardiac arrest in a porcine model: Possible role of the renin-angiotensin system. Int. J. Mol. Sci. 2015, 16, 27015-27031. [CrossRef]

25. Korkmaz-Icöz, S.; Radovits, T.; Szabó, G. Targeting phosphodiesterase 5 as a therapeutic option against myocardial ischaemia/reperfusion injury and for treating heart failure. Br. J. Pharmacol. 2018, 175, $223-231$. [CrossRef] [PubMed]

26. Mohey, V.; Singh, M.; Puri, N.; Kaur, T.; Pathak, D.; Singh, A.P. Sildenafil obviates ischemia-reperfusion injury-induced acute kidney injury through peroxisome proliferator-activated receptor $\gamma$ agonism in rats. Surg. Res. 2016, 201, 69-75. [CrossRef] [PubMed]

27. Guerra-Mora, J.R.; Perales-Caldera, E.; Aguilar-León, D.; Nava-Sanchez, C.; Díaz-Cruz, A.; Díaz-Martínez, N.E.; Santillán-Doherty, P.; Torres-Villalobos, G.; Bravo-Reyna, C.C. Effects of sildenafil and tadalafil on edema and reactive oxygen species production in an experimental model of lung ischemia-reperfusion injury. Transplant. Proc. 2017, 49, 1461-1466. [CrossRef] [PubMed]

28. Savvanis, S.; Nastos, C.; Tasoulis, M.K.; Papoutsidakis, N.; Demonakou, M.; Karmaniolou, I.; Arkadopoulos, N.; Smyrniotis, V.; Theodoraki, K. Sildenafil attenuates hepatocellular injury after liver ischemia reperfusion in rats: A preliminary study. Oxid. Med. Cell. Longev. 2014, 2014, 161942. [CrossRef]

29. Ozdegirmenci, O.; Kucukozkan, T.; Akdag, E.; Topal, T.; Haberal, A.; Kayir, H.; Oter, S.; Akyol, M.; Uzbay, T. Effects of sildenafil and tadalafil on ischemia/reperfusion injury in fetal rat brain. J. Matern. Fetal Neonatal Med. 2011, 24, 317-323. [CrossRef]

30. Kulkarni, S.K.; Patil, C.S. Phosphodiesterase 5 enzyme and its inhibitors: Update on pharmacological and therapeutical aspects. Methods Find. Exp. Clin. Pharmacol. 2004, 26, 789-799. [CrossRef]

31. Dussault, S.; Maingrette, F.; Ménard, C.; Michaud, S.E.; Haddad, P.; Groleau, J.; Turgeon, J.; Perez, G.; Rivard, A. Sildenafil increases endothelial progenitor cell function and improves ischemia-induced neovascularization in hypercholesterolemic apolipoprotein E-deficient mice. Hypertension 2009, 54, 1043-1049. [CrossRef]

32. Valatsou, A.; Briasoulis, A.; Vogiatzi, G.; Pantopoulou, A.; Oikonomo, E.; Miliou, A.; Perrea, D.; Tousoulis, D. Beneficial effects of sildenafil on tissue perfusion and inflammation in a murine model of limb ischemia and atherosclerosis. Curr. Vasc. Pharmacol. 2017, 15, 282-287. [CrossRef]

33. Constantinescu, I.M.; Bolfa, P.; Constantinescu, D.; Mironiuc, A.I.; Gherman, C.D. Treatment with sildenafil and donepezil improves angiogenesis in experimentally induced critical limb ischemia. Biomed. Res. Int. 2017, 2017, 9532381. [CrossRef] [PubMed]

34. Thaveau, F.; Zoll, J.; Rouyer, O.; Chafke, N.; Kretz, J.G.; Piquard, F.; Geny, B. Ischemic preconditioning specifically restores complexes I and II activities of the mitochondrial respiratory chain in ischemic skeletal muscle. J. Vasc. Surg. 2007, 46, 541-547. [CrossRef] [PubMed]

35. Charles, A.L.; Guilbert, A.S.; Guillot, M.; Talha, S.; Lejay, A.; Meyer, A.; Kindo, M.; Wolff, V.; Bouitbir, J.; Zoll, J.; et al. Muscles susceptibility to ischemia-reperfusion injuries depends on fiber type specific antioxidant level. Front. Physiol. 2017, 6, 52. [CrossRef] [PubMed] 
36. Flück, M.; von Allmen, R.S.; Ferrié, C.; Tevaearai, H.; Dick, F. Protective effect of focal adhesion kinase against skeletal muscle reperfusion injury after acute limb ischemia. Eur. J. Vasc. Endovasc. Surg. 2015, 49, 306-313. [CrossRef] [PubMed]

37. Tran, T.P.; Tu, H.; Liu, J.; Muelleman, R.L.; Li, Y.-L. Mitochondria-derived superoxide links to tourniquet-induced apoptosis in mouse skeletal muscle. PLoS ONE 2012, 7, e43410. [CrossRef]

38. Miura, S.; Saitoh, S.I.; Kokubun, T.; Owada, T.; Yamauchi, H.; Machii, H.; Takeishi, Y. Mitochondrial-targeted antioxidant maintains blood flow, mitochondrial function, and redox balance in old mice following prolonged limb ischemia. Int. J. Mol. Sci. 2017, 18, 1897. [CrossRef]

39. Koutakis, P.; Weiss, D.J.; Miserlis, D.; Shostrom, V.K.; Papoutsi, E.; Ha, D.M.; Carpenter, L.A.; McComb, R.D.; Casale, G.P.; Pipinos, I.I. Oxidative damage in the gastrocnemius of patients with peripheral artery disease is myofiber type selective. Redox Biol. 2014, 2, 921-928. [CrossRef] [PubMed]

40. Frankenreiter, S.; Groneberg, D.; Kuret, A.; Krieg, T.; Ruth, P.; Friebe, A.; Lukowski, R. Cardioprotection by ischemic postconditioning and cyclic guanosine monophosphate-elevating agents involves cardiomyocyte nitric oxide-sensitive guanylyl cyclase. Cardiovasc. Res. 2018, 114, 822-829. [CrossRef] [PubMed]

41. Veres, G.; Hagenhoff, M.; Schmidt, H.; Radovits, T.; Loganathan, S.; Bai, Y.; Korkmaz-Icöz, S.; Brlecic, P.; Sayour, A.A.; Karck, M.; et al. Targeting phosphodiesterase-5 by vardenafil improves vascular graft function. Eur. J. Vasc. Endovasc. Surg. 2018, 56, 256-263. [CrossRef] [PubMed]

42. Bloom, T.J. Cyclic nucleotide phosphodiesterase isozymes expressed in mouse skeletal muscle. Can. J. Physiol. Pharmacol. 2002, 80, 1132-1135. [CrossRef] [PubMed]

43. Fernandes, M.A.; Marques, R.J.; Vicente, J.A.; Santos, M.S.; Monteiro, P.; Moreno, A.J.; Custódio, J.B. Sildenafil citrate concentrations not affecting oxidative phosphorylation depress $\mathrm{H}_{2} \mathrm{O}_{2}$ generation by rat heart mitochondria. Mol. Cell. Biochem. 2008, 309, 77-85. [CrossRef] [PubMed]

44. Aksu, V.; Yüksel, V.; Chousein, S.; Taştekin, E.; İşcan, Ş.; Sağiroğlu, G.; Canbaz, S.; Sunar, H. The effects of sildenafil and n-acetylcysteine on ischemia and reperfusion injury in gastrocnemius muscle and femoral artery endothelium. Vascular 2015, 23, 21-30. [CrossRef] [PubMed]

45. Karamatsoukis, S.L.; Trigka, E.A.; Stasinopoulou, M.; Stavridou, A.; Zacharioudaki, A.; Tsarea, K.; Karamperi, M.; Pittaras, T.; Papadopoulos, O.; Patsouris, E.; et al. Beneficial Effect of U-74389 G and sildenafil in an experimental model of flap ischemia/reperfusion injury in swine. Histological and biochemical evaluation of the model. J. Investig. Surg. 2018, 30, 1-13. [CrossRef] [PubMed]

46. Armstrong, D.M.; Armstrong Ada, C.; Figueiredo, R.C.; Florentino, J.E.; Saad, P.F.; Fox-Talbot, K.; Halushka, M.K.; Berkowitz, D.E.; Taha, M.O.; Fagundes, D.J. Sildenafil citrate protects skeletal muscle of ischemia-reperfusion injury: Immunohistochemical study in rat model. Acta Cir. Bras. 2013, 28, $282-287$. [CrossRef] [PubMed]

47. Walker, D.K.; Ackland, M.J.; James, G.C.; Muirhead, G.J.; Rance, D.J.; Wastall, P.; Wright, P.A. Pharmacokinetics and metabolism of sildenafil in mouse, rat, rabbit, dog and man. Xenobiotica 1999, 29, 297-310. [CrossRef] [PubMed]

48. Nio, Y.; Tanaka, M.; Hirozane, Y.; Muraki, Y.; Okawara, M.; Hazama, M.; Matsuo, T. Phosphodiesterase 4 inhibitor and phosphodiesterase 5 inhibitor combination therapy has antifibrotic and anti-inflammatory effects in mdx mice with Duchenne muscular dystrophy. FASEB J. 2017, 31, 5307-5320. [CrossRef] [PubMed]

49. Broome, S.C.; Woodhead, J.S.T.; Merry, T.L. Mitochondria-targeted antioxidants and skeletal muscle function. Antioxidants 2018, 8, 7. [CrossRef]

(C) 2019 by the authors. Licensee MDPI, Basel, Switzerland. This article is an open access article distributed under the terms and conditions of the Creative Commons Attribution (CC BY) license (http://creativecommons.org/licenses/by/4.0/). 